\title{
Construction of Pre Judges Through Judicial Reconstruction Commissioners and Representatives of Protected Rights
}

\author{
Joko Sriwidodo ${ }^{1}$ \\ \{jokosriwidodo@ymail.com ${ }^{1}$ \} \\ Faculty of Law, Jayabaya University, Jakarta ${ }^{1}$
}

\begin{abstract}
To overcome the implementation of the Draft Criminal Procedure Code/ RUU KUHAP with legal instruments that are more concrete and easy to implement, the Government and the DPR must consider the existence of a Judicial Commissioner in the Criminal Procedure Code/ KUHAP. The presence of the Judicial Commissioner is expected to provide protection to the defendants, in the process of being investigated by investigators, prosecutors until the defendant is finally convicted. On the other hand, it is necessary to regulate facilities and infrastructure for commissioner judges so that the handling can run in accordance with the provisions of laws and regulations. Such a formulation is a feature of formal criminal law so that it is easily understood by the public, especially those who will become candidates or convicted suspects, and as a means of controlling the use of powers given to the law. law enforcement officers. The basic legal principle is that deprivation of the rights of others should not be carried out unless there is an authority to confiscate (detain) and this authority is exercised based on a court decision or court / court's permission.
\end{abstract}

Keywords: Judicial Reconstruction Commissioners; Representatives of Protected Rights; Criminal Procedure Code/ KUHAP.

\section{Introduction}

Construction in the current criminal procedural law when it is associated with the judicial process, especially in pre-trial, it is time to be changed by reconstruction especially in the procedural law concerning pre-trial.

Attempts to understand law as part of the history of human life never culminate in a common understanding among community groups. Between the group of ordinary people and groups of people engaged in the field of law both as legal practitioners and as academics of jurisprudence have different views about the phenomenon called law. Even among the people within each group is open the possibility of inequality of understanding because of differences in experience in dealing with the law. Human life has many aspects or areas and each requires regulation by law. The diversity of the law in the context of the diversity of aspects in human life makes it impossible to unite it in a single formula. ${ }^{1}$

For practitioners especially those included in the Five House of Law Enforcers such as police, prosecutors, judges, lawyers including legal consultants, and the Press, the law is

\footnotetext{
${ }^{1}$ Apeldoorn, L.J. van, Pengantar Ilmu Hukum, Pradnya Paramita, Jakarta, 1975, hlm. 13.
} 
understood from the standpoint and their respective roles. For the police and prosecutors, the law is better understood as a guide and an instrument to investigate the perceived behavior of the deviant and the legitimacy of the effort to put the target legal proceedings. For judges, the law is better understood as a steering through the method of deductive thinking as well as giving legitimacy to conduct an assessment of the true or false validity of legal behavior that is tried. For lawyers, law is understood as an instrument to fight for the interests of those who need their services in various forms. For the press, the law is understood as a steering and instrument to control the behavior of citizens and especially the behavior of state officials in order not to deviate from the goal to be achieved. In addition to the normative and functional understanding of such practitioners, it is not impossible to develop a legal understanding as an instrument for the pragmatic-economic or pragmatic-political pragmatic individual interests of law practitioners through the use of loopholes or holes that are textually contained within existing legal norms. This means that the law is used to justify the abuse of power for economic or political purposes.

This can be seen in the decision of Pre Judicial Budi Gunawan and Setya Novanto, they are in the process of pre-judicially stated not guilty. Unlike the other defendant on the other case such as late Sutan Batugana, his pre-trial was rejected by the judge.

One of the rulings considered controversial is the verdict. 04 / Pid.Prap / 2015 / PNJaksel dated February 16, 2015 filed by the applicant of the Police Commander Drs. Gunawan, SR Msi. Fighting the Corruption Eradication Commission (KPK) which has established the Petitioner as a suspect of corruption, because surprisingly Mr. Sarpin, SH who became the Sole Judge in the pre-trial case granted the pre-trial suit filed by the Petitioner and defeated the KPK and in one of its decisions stated that Letter of The Investigation Order Number: Sprin.Dik / 03/2015 dated January 12, 2015 which has established the Petitioner as a suspect of corruption is illegal and not based on law and therefore aquo determination does not have binding power, and also at the same time declared the investigation conducted by the invalid petitioner and has no binding legal force.

The ruling has generated tremendous controversy even leading to a wave of protests from many jurists as well as provoking the Judicial Commission (KY) to respond and even to the examination of ethical behavior violations of judges allegedly perpetrated by a judge Sarpin.

Law No. 8 of 1981 on the Criminal Procedure Code (KUHAP) which has been more than a quarter century (+32 years), is often referred to as the work of "majesty" of the Indonesian nation, a law made by experts Indonesian criminal procedure law accompanied by integrity and spirit to realize the administration of government that protect the interests of citizens in accordance with the Preamble of the 1945 Constitution.

The Criminal Procedure Code was created to replace the Herziene Indische Reglement (HIR), the creation of the Dutch colonial government. In the substance of the existing KUHAP there are some shortcomings as well as in the field of science and technology that must be anticipated by the Indonesian government to criminal procedure law is not left behind with the developments in the era of globalization, especially about various forms of crime, given the development of the current era of globalization of crime also experiencing progress along with the development of economic globalization, as well as the advancement of science and technology. ${ }^{2}$

Regarding this matter in the Criminal Procedure Code (Law No. 8 of 1981) does not occurred, a defendant may be detained without notice to his family and usually suspects of torture while detained. As experienced by a Narcotics Bandar arrested and detained without a

\footnotetext{
${ }^{2}$ Supanto, Kejahatan Ekonomi Global dan Kebijakan Hukum Pidana, Bandung: Alumni, 2010, hlm. 15
} 
warrant and when the pre-trial was found guilty, because at the same time the defendant file was delegated to the Public Prosecutor. ${ }^{3}$ This provision should be immediately given due attention in ICCPR ratified through Law Number 12 Year 2005 About Ratification of International Covenant on Civil and Political Right (Covenant of International Civil and Political Rights).

From the above description can be drawn a common thread that the Criminal Procedure Code in Indonesia which is more than a quarter of a century must also be updated to fit the dynamics of science and technology, as well as changes in society and international provisions that developed advanced related to criminal procedural law. The various ratifications of some of the ICCPR's special international conventions directly related to criminal procedural law on detention by investigators should be as short as possible and at most two times twenty-four hours. In Europe a long period of detention is defined as a maximum of 5 (five) days or 1 (one) day of arrest and 4 (four) days of detention, while in the Criminal Procedure Code 20 days is considered too long and contrary to International Convention Against Torture and International Covenant on Civil and Political Rights (ICCPR), which has been ratified by Indonesia with Law Number 12 Year 2005 even though the date the ratification is different, in its implementation must be applicable considering the human rights of the accused.

The idea of pre-judiciary was born out of inspiration derived from the rights of Habeas Corpus in the Anglo Saxon court, which provides a fundamental guarantee of human rights to the right to freedom. Habeas Corpus is a guarantee and security of personal liberty through a simple, straightforward and open procedure that anyone can use, Habeas Corpus's right is to be able to provide protection to a person suspected of committing an offense against an unauthorized examination. ${ }^{4}$

Through the Habeas Corpus Act, a person with a court order may sue a detaining official to prove that the detention is not illegal or completely legitimate in accordance with applicable law. ${ }^{5}$

In contrast to the review of forced attempts through pre-trial, the court order containing the rights of Habeas Corpus is not only directed to the relevant detention in the criminal justice process, but also against any form of detention that is deemed to have infringed a person's personal liberty rights guaranteed by constitution. In the development of Habeas Corpus warrant became one of the tools of supervision and improvement of the criminal process both at federal and state level in the United States. ${ }^{6}$

The rationale for the amendment of Law No. 8 of 1981 by adding the existence of Judge Commissioner as an effort to protect human rights of the defendant, both in the process of investigation and prosecution, is based on several thoughts as follows: ${ }^{7}$

1. Philosophical Reason

The philosophical foundation is the ideal foundation, the instrument of law and can motivate law enforcement officers to pursue and direct the spirit and dedication of law enforcement, trying to realize the noble meaning and essence contained in the soul of the philosophical foundation of Pancasila.

2. Juridical Reason

\footnotetext{
${ }^{3}$ Ahmad Ubbe, Proses Pengadilan dalam Perkara Pidana, Jakarta: BPHN- KemkumHam, 2009, hlm. 2

${ }^{4}$ Andi Hamzah, Op.Cit., hlm. 12

${ }^{5}$ Ibid

${ }^{6}$ Ibid

${ }^{7}$ Yanto, Hakim Komisaris dalam Upaya Perlindungan Terhadap Hak Asasi Manusia, Disertasi, Jakarta: FH Jayabaya, 2010, hlm. 127
} 
The 1945 Constitution, especially in the provisions of Article 20, on the legislation, Article 21 of the right of the People's Legislative Assembly to submit the Bill, Article 22 of the right of the President to file a Perpu (rules made by President without the consent from legislative, usually force majeur), Article 22A of the law-making procedure, Article 24 judicial authority, Article 24A authority of the Supreme Court, Article 24C The Constitution, Article 28A to Article 28J human rights.

3. Sociological Reasons

The community of justice seekers at some point often complains about various matters relating to criminal proceedings that tend to be long and convoluted, which is very detrimental to the justice seekers, both in terms of time, effort and cost.

4. Reasons for Efficiency and Effectiveness

The procedural law will relate to the constitutional rights of citizens, if the stages determined by the criminal procedural law can be effective and effective, it will benefit not only citizens dealing with criminal matters but also law enforcement processes by the state more efficiently and effectively.

5. Economic Basis

All articles in the Criminal Procedure Code refer to the rapid judicial system (speedy trial, contante justitie) simple and affordable costs. The introduction of the judiciary is quickly put forth in the filing of the case through an off-site special settlement (afdoening buiten process) in the legal proceedings of all cases must pass a new Court of Appeal can be filed an appeal to the Supreme Court to reduce the burden of the Supreme Court.

While the enactment of Law No. 8 of 1981 on the Criminal Procedure Code in the preindependence period, enacted two criminal procedural laws namely the criminal procedure for the European class underway Srafvordering (sv) and criminal procedure law for indigenous groups apply Inland Reglement (IR) later renewed to Herziene Indische Reglement (HIR) with Staatsblad No. 44 of 1941. The procedural law for the European class has a better form of criminal procedural law and more respect for the human rights of the accused than with the arrangement of criminal procedure law in the Inland Reglement or Herziene Indische Reglement (HIR) imposed on the Indigenous people who at the time was his position as a citizen in the Dutch colony. ${ }^{8}$

This is as it is known in the case of a person in an inadequate process of investigation conducted by the investigator and the public prosecutor where the suspect in the process of examination always get the physical and psychological intimidation as happened in 1978 in the case of Sengkon and Karta who were charged with murder to the family in Bekasi. In examination (two) the person does not acknowledge his actions, but the investigator and prosecutor still insist that they are the perpetrators. The law does not side with people who are weak and do not understand their rights, and officers with authority always try to solve the problem without seeing the applicable law. Both are accused of robbing and killing. Not feeling guilty, Sengkon and Karta initially refused to sign the examination report. But because they could not bear the torture of the police, the two then gave up. Judge Djurnetty Soetrisno trusted the Police case news rather than the defendant's two denials. So in October 1977, Sengkon was sentenced to 12 years in prison, and Karta was 7 years old. The verdict was upheld High Court of West Java. It was in the cold walls that they met a jailer named Genul, Sengkon's nephew, who was imprisoned for theft. This is where the real murderer unlocks the secrets: he is the killer of Sulaiman and Siti. Finally, in October 1980, Gunel was sentenced to

${ }^{8}$ Ibid; 
12 years in prison. Even so, it does not necessarily make them free. Because previously they did not appeal, so the verdict is declared to have a permanent legal force.

Based on the above, the Government together with the DPR-RI made a breakthrough by making the Criminal Procedure Code more protective of the human rights of the suspect, containing in the Regulation on Judicial Review (PK) as well as the regulation on compensation issues. ${ }^{9}$ Luckily there's Albert Hasibuan, a lawyer and a councilman who staunchly fights for their lot. Finally, in January 1981, Chief Justice of the Supreme Court (MA) Oemar Seno Adji ordered that both be released through the review. ${ }^{10}$ However, after being released, their rights have been ignored by the government to provide restitution because of wrong handling of the case, until the second (2) of their rights are not given. This provision raises the need for a Criminal Procedure Code as a container in the process of proceeding in criminal justice. The case of Sengkon and Karta has passed and Indonesia has a new procedural law that is Law No. 8 of 1981, which in its journey contains some elementary weaknesses in case engineering and has been left behind by the existence of the rules of international law on human rights of the accused. As experienced by Imam Chambali aka Kemot and David Eko Priyanto who in the process of examination undergoing intimidation, torture by POLRI investigators to obtain the results of investigators to be submitted to the Prosecutor General.

The pre-trial institutions of its presence are inconsistent with the initial idea of the will of this institution as a protection against widespread deviance of dwang middelen from the law enforcement apparatus at the same time not in accordance with the intention of the existence of human rights protection for the parties involved in a renewal against Law No. 8 of 1981 so that impressed the absence of integrated criminal justice system. ${ }^{11}$

In order to anticipate this, the main thing is to revise the Criminal Procedure Code by presenting the Judicial Commissioner who acts to replace pre-trial institution; the authority of pre-trial institutions is not as effective as the justice seeker hopes. In addition, Article 50 of the Criminal Procedure Code also states that: Any person committing acts to enforce the provisions of a law shall not be subject to criminal sanction.

It can be said here that pre-trial is a more repressive and non-preventive measure. ${ }^{12}$ In pretrial a person may sue the investigator (POLRI) or the prosecutor, but in reality the pre-trial has always failed, because the case was handed over to the court, so the pre-trial suit is declared a failure. In contrast to the preliminary hearing process used by Common Law and United States system which conducted prior to examination of the subject matter but on a different basis.

The Preliminary Hearing function is performed as an attempt by the judge to examine whether there is a probable cause for believing that a particular suspect is the perpetrator of a crime and therefore has sufficient grounds to be detained and tried.$^{13}$ In the preliminary forum of the court the official concerned filed a petition for detention and search before the forced attempt was made. So it can be said that the judges in the above processes have the authority

\footnotetext{
${ }^{9}$ Indriyanto Seno Adji, KUHAP dalam Perspektif, Jakarta: Diadit Media, 2011, hlm. 45

${ }^{10} \mathrm{http}: / /$ dekade80.blogspot.com/2009/04/sengkon-dan-karta-sebuah-ironi-keadilan.html di unduh pada tanggal 7 April 2018

${ }^{11}$ Indriyanto Seno Adji, KUHAP dalam Prospektif, Jakarta: Diadit Media, 2011, hlm. 2

${ }^{12}$ Loebby Loqman. Pra peradilan di Indonesia. Jakarta: Ghalia Indonesia, 1984, hlm. 51. Diambil dari Gregory Churchill. Habeas Corpus: Peranan Upaya Habeas Corpus Dalam Pengawasan Pelaksanaan Hukum Acara Pidana di Amerika Serikat. Seminar Pra peradilan , PERADIN. Jakarta, 1982

${ }^{13}$ Ibid
} 
as examining and investigating judges because in addition to overseeing the course of forced efforts, they also provide advice in the implementation of such force efforts. ${ }^{14}$

The initial inspection process is important in a criminal act, in an attempt to protect a defendant from errors that can be committed by both of the investigator, the prosecutor and the judge in imposing a criminal offense. Although the provisions have been made by investigators, prosecutors and judges, but in reality does not always provide justice for the justice seekers, therefore criminal procedure law must be able to make breakthroughs in the prosecution process by presenting the Judge Commissioner.

Before discussing the construction and reconstruction more deeply, first explained about the understanding of the construction is an activity to build facilities and infrastructure. In a field of architecture or civil engineering, a construction is also known as a building or unit of infrastructure in an area or in some areas. In summary construction is defined as the overall object of the building which consists of parts of the structure. For example, Building Structure Construction is the overall form / build of the building structure. Other examples: Highway Construction, Bridge Construction, Ship Construction, etc., are no exception in the field of law, especially criminal law. While reconstruction by B.N. Marbun is the return of something to its original place, the compilation or reconstitution of the existing materials and reconstituted as they were or the original occurrence. This is done for the protection of the defendant in the criminal justice process concerning his / her rights.

The law can be perceived and manifested in the simplest form of legislation. In a more complicated form, the form of the law is controlled by a number of legal principles, doctrines, theories, or philosophies, recognized by the universals' legal system. ${ }^{15}$

The doctrine of equality before the law or so-called the doctrine of equality, according to Albert Dicey, was born as a reaction due to the treatment of tyrants run by Anglo Saxon nobles in England. ${ }^{16}$ King John stopped the treatment by issuing Magna Charta containing the doctrine. ${ }^{17}$ Therefore, it can be said that the expression of equality before the law was born from the British common law system. The various principles of the protection of the human rights of suspects, defendants and convicted persons through national and international criminal law can be seen from the following table which provides some similarities between the ICCPR provisions, UDHR provisions and other provisions adopted in the Law of Material Criminal and Indonesian Criminal Law.

ICCPR as an international convention which is now a positive law in Indonesia has many similarities with the Criminal Procedure Code. Various provisions on the rights of suspects,

${ }^{14}$ Ibid

15 Pengertian universal dalam tulisan ini mengacu kepada teori, asas, maupun doktrin hukum yang berlaku sebagai hukum positif dan termaktub dalam peraturan perundang-undangan di Indonesia maupun negara-negara lain di dunia. Sekalipun harus diakui bahwa terdapat juga sistem hukum lain yang berlaku di Indonesia, yaitu sistem hukum adat dan sistem hukum agama, yang tidak tertulis atau tidak bersifat hukum positif.

${ }^{16}$ Bhardwaj, H.R., Crime, Criminal Justice \& Human Rights, New Delhi, Konark Publisher Pvt. Ltd., 2001, hlm. 5.

${ }^{17}$ Magna Carta yang berarti The Great Charter, adalah suatu resolusi atau pernyataan yang dibuat oleh Raja Inggris, John, pada tahun 1215. Di dalam pernyataan Raja tersebut mengakui hak-hak rakyat atas tanah dan mencegah para bangsawan untuk bertindak sewenang-wenang. Raja John meninggal setahun kemudian, digantikan oleh putranya yang berusia 9 tahun, Henry III. Magna Carta telah beberapa kali direvisi, yaitu pada tahun 1216, tahun 1217 dan tahun 1225. Lihat The Magna Carta (The Great Charter), <http: / /www.constitution.org/eng/magnacar.htm>, dikutip pada tanggal 15 April 2005. 
defendants and convicts set forth in the ICCPR have been accommodated in the Criminal Procedure Code. However, it can also be seen that as a guideline for the Criminal Justice System, the Criminal Procedure Code is incomplete and does not reflect system regulation which is synchronous and integrated. There are still many provisions on the protection of the rights of suspects, defendants and convicted persons who have not been regulated in the Criminal Procedure Code. Some human rights are not even regulated as rights, but are applied as guidelines for the administration of justice. This leads to differences in perceptions among law enforcers, in particular prosecutors and investigators who consider them unnecessarily subject to these provisions because they only deal with justice. A concrete example in this case is the obligation of rapid judicial administration. It should be understood that it is not just the courts that must be fast in carrying out their duties, but also the process of investigation. The task of protecting human rights is not new at the court stage, but has started since the investigation stage.

Independence and freedom of a person contain a broad aspect. One aspect is the right of a person to be treated fairly, non-discriminatory and lawful, especially if a person is suspected or suspected of committing an offense or an act of crime. That is to say, the deprivation or restriction of liberty and freedom of movement of a person suspected of committing a criminal offense, in view of the Criminal Law may be arrest, detention and punishment, justified by virtue of existing laws and regulations which existed before any legal action was imposed on him.

It implies that there are certain rights of a person who is arrested, detained or sentenced to be fulfilled. These rights include:

1. The right to know the basis or reason for the arrest, detention and / or imposition of a criminal against him / her. ${ }^{18}$

2. The right to receive humane treatment and rights in accordance with applicable legislation, during the period of arrest, detention or during the course of his or her crime. $^{19}$

3. Right to express opinions both orally and in writing. ${ }^{20}$

4. The right to silence, in the sense of not issuing statements or acknowledgments. Thus, no particular pressures are allowed. The right is expressly stated in Article 52 of the Criminal Procedure Code. ${ }^{21}$

In addition to the rights mentioned above, in examination at the level of investigation and trial, the suspect or defendant has rights including:

1. The right to freely give information to the investigator or judge;

2. The right to be given an interpreter at any time;

3. The right to legal assistance from a person or more of legal counsel during and at each examination level; ${ }^{22}$

${ }^{18}$ Hak-hak tersebut tercakup dalam Pasal 50, 51 dan Pasal 59 KUHAP (UU Nomor 8 Tahun 1981).

${ }^{19}$ Hak-hak tersebut ditetapkan dalam Pasal 52-68 KUHAP.

${ }^{20}$ Hak-hak tersebut diatur di dalam Pasal 60-63 KUHAP.

${ }^{21}$ Pasal 52 KUHAP: "Dalam pemeriksaan pada tingkat penyidikan dan pengadilan, tersangka atau terdakwa berhak memberikan keterangan secara bebas kepada penyidik atau hakim."

${ }^{22}$ Untuk mendapatkan penasihat hukum, tersangka atau terdakwa berhak memilih sendiri penasihat hukumnya. Dalam hal tersangka atau terdakwa disangka atau didakwa melakukan tindak pidana yang diancam dengan pidana mati atau ancaman pidana lima belas tahun atau lebih atau bagi mereka yang tidak mampu yang diancam dengan pidana lima tahun atau lebih yang tidak mempunyai penasihat hukum sendiri, pejabat yang bersangkutan pada semua tingkat pemeriksaan dalam proses peradilan 
4. The right to contact and receive visits of his or her personal physician for the benefit of health whether or not related to the proceedings of the case; ${ }^{23}$

5. The right to be notified of his or her detention by the competent authorities at any level of examination, to his family or any other person in the house with him; ${ }^{24}$

6. The right to be tried in public court proceedings, as well as the right to prosecute and to bring witnesses and / or persons with special expertise in order to provide information which is favorable to him / her; ${ }^{25}$

7. The right to send a letter to his legal counsel and to receive a letter from his or her legal counsel and relative whenever it is required by him, for the purpose of the suspect or defendant to be provided with writing instruments; ${ }^{26}$

8. The right to claim compensation and rehabilitation for being arrested and detained without any statutory ordinances.

Indemnification and rehabilitation through pre-trial hearing is a form of restoration of the rights of suspects and defendants compensated by a certain amount of money. The compensation does not reflect a sense of justice and must go through a long bureaucracy awaiting the decision of the Minister of Finance. By the Police, the Minister of Finance's permit is either in the form of a letter or a decision is the basis of indemnification, whereas the compensation is included in the court decision. For example, the case of Sudarto's ${ }^{27}$ death with monetary compensation is only Rp. 500.000, -.

Limitations of the authority of the Pre-Judicial and also the passive nature of pre-trial judges in the Criminal Procedure Code during this time raises many doubts about its ability to protect the rights of suspects, especially from the actions of repressive law enforcement officers. In such circumstances it is impressed that pre-trial institutions become defenseless and not humanistic because they are unable or less able to protect suspects from possible violations of their juridical rights by criminal law enforcement officers at the preliminary examination level.

In most cases, pre-trial application whose material is outside the provisions of Article 77 of KUHAP is not granted and / or rejected because the judge thinks conventionally based solely on the provisions of KUHAP in the juridical normative perspective, but in this theme we will get a judge's perspective. unlike most judges who have tried pre-trial cases, there is a more progressive perspective by looking at various aspects relating to the background of the emergence of pre-trial institutions whose sole purpose is to protect the suspect's human rights from the possibility of becoming a victim of abuse of criminal law enforcement authorities in preliminary examination level, then before this progressive judge is the pre-trial cases whose material is outside Article 77 of the Criminal Procedure Code as well as in the decision of the

wajib menunjuk penasihat hukum bagi mereka, di mana penasihat hukum tersebut memberikan bantuannya dengan cuma-cuma. Lihat Pasal 56 KUHAP.

${ }^{23}$ Lihat Pasal 58 KUHAP

${ }^{24}$ Lihat Pasal 60 KUHAP

${ }^{25}$ Lihat Pasal 64 dan 65 KUHAP.

${ }^{26}$ Lihat Pasal 62 KUHAP.

${ }^{27}$ Sudarto ditangkap anggota polisi dan Polres Jakarta Utara pada tanggal 25 April 1985 atas dugaan sebagai pelaku perampokan di sebuah toko emas di Desa Mauk, Tangerang yang terjadi sehari sebelum penangkapan berlangsung. Pada tanggal 26 April 1985, keluarga dikejutkan oleh kabar kematian Sudarto dalam tahanan Polres Metro Jakarta Utara. Kondisi jasad Sudarto ketika dibawa ke rumah keluarganya sangat mengenaskan. Lehernya patah, kelopak mata terkelupas dan kuku jari tangannya terkelupas. Lihat Kaligis, O.C. Praktik Pra peradilan Dari Waktu Ke Waktu, Otto Cornelis Kaligis \& Associates, Jakarta, tahun 2000, hlm. 109-110. 
case no. 04 / Pid.Prap / 2015 / PNJaksel on February 16, 2015 is acceptable and granted. Although the pre-trial decision is not the first time, because previously in the same district court (South Jakarta District Court) there has also been a pre-trial verdict. 38 / Pid.Prap / 2012 / PN.Jkt-Cell filed by Bachtiar Abdul Fatah against the Attorney General of Indonesia, known as Chevron Bio Remediation case, which also granted the judge when the material is also outside the provisions of KUHAP. Likewise in pre-trial case No. 36 / Pid.Prap / 2015 / PN JktSel submitted by former Chief of BPK Hadi Poernomo, and long before any such case has aroused a long and controversial debate, especially in the verdict. 04 / Pid.Prap / 2015 / PNJaksel dated February 16, 2015 filed by the applicant of the Commander. Police Drs. Budi Gunawan, SH. Msi. Against the Corruption Eradication Commission (KPK), although in fact in 2001 in Sleman District Court there was also a decision of Pre-Court No. 01 / Pre.Pid / 2001 / PN SImn where the judge also granted the Petitioner's petition so that the investigation handled by the DI Yogyakarta Police Investigator was declared invalid and against the Law and therefore the Petitioners (Polda DIY) were ordered to stop the investigation.

The granting of a pre-trial request whose material is beyond the provisions of Article 77 of the Criminal Procedure Code does not need to be responded negatively, nor should it be appreciated positively along the motive or the reasons used by the judge in making the verdict true and not against the law and not motivated by abuse of authority, which has been decided by the judge is to grant the Pre-Judicial application whose material is outside the provisions of Article 77 of the Criminal Procedure Code there is a strong legal justification now that is with the decision of the Constitutional Court No. 21 / PUU ᄀXII / 2014 which extends the jurisdiction of pre-trial judges to examine and decide on the validity of the determination of the suspect as measured by the fulfillment of sufficient preliminary evidence of at least two valid evidences, and the latter of which should be given attention from the perspective of future law (ius constitutum), in the draft of the new Criminal Code has also contained the extension of authority pre-trial is not only about its authorization to verify the validity of the suspect's determination, the validity of the investigation and prosecution, but also to examine any losses suffered by the suspect or any interested parties arising from the unlawful action of the investigator.

The term Judge of the Preliminary Examination (Judge Commissioner) is actually not a new item in Indonesia, because at the time of enactment of the Reglement op de Strafvoerdering, it is set in the second title of Van de regter-commissaris functioning at the preliminary examination stage to oversee whether the act of forced effort (dwang middelen), which includes arrest, searches, seizure and inspection of letters, is done legally or not. In addition, in the Reglement op de Strafvoerdering the Judge Commissioner or regimental cimmissaris may conduct an investigating judge to summon persons, both witnesses and suspects, to the homes of witnesses and suspects, as well as to examine and hold temporary detention of suspects. However, the application of Herziene Indische Reglement (HIR) with Staatsblad. 44 In 1941, the term regiss commissaris was not used anymore.

Furthermore, the term Judge Commissioners began to reappear in the draft Law of Criminal Procedure Law submitted to the House of Representatives in 1974, during Prof. Oemar Seno Adjie, SH, served as Minister of Justice. In this concept, the Judicial Commissioner has the authority at the examination stage (dwang middelen), acting executive to participate in leading the implementation of the forced effort, determining which investigator conducts an investigation in case of dispute between the police and the prosecutor, and making a decision on the objections raised by the parties which is subject to action. The background for the introduction of Judicial Commissioners is to better protect human rights guarantees in criminal proceedings and avoid congestion by the incidence of 
differences between investigative officers from different agencies. Unlawful arrest and detention is a serious violation of the human rights of freedom and freedom. Illegal seizure is a forced breach must be approved by the court, as well as Amir Syamsuddin said the importance of the judge commissioner to reduce the arbitrary actions perpetrated by law enforcement officers in the forced effort. In practice, many complaints suffered by victims related to forced efforts by law enforcement officers who were considered to violate human rights. ${ }^{28}$ Prof. Andi Hamzah, ${ }^{29}$ said that in principle the judge of this examiner is the same as the current pre-trial judge, the authority added with the extension of the search warrant detention, seizure, permit wiretapping. It aims to reduce the burden of judges of state courts, so that they can concentrate on civil, criminal, and so on. A person who does not receive his arrest, for example, can file a complaint to a preliminary examiner judge. ${ }^{30}$

\section{Problem Formulation}

The formulation of the problem in writing this paper is as follows:

How is the construction of a commissioner's judge as an effort to protect the human rights of the suspect in the Indonesian Criminal Justice System?

\section{Discussion}

Legal justice for people in this country is an expensive item. Legal justice is only owned by people who have power, political and economic access only. Meanwhile, poor or poor communities are relatively difficult to gain access to legal justice, in fact they are often victims of unjust law enforcement. This phenomenon of legal injustice continues to occur in the practice of law in this country. The emergence of various protests against law enforcement officers in various region, shows the system and practice of law is currently in trouble, as according to Ahmad Ali, the supremacy and legal justice that became the desire of society never materialized in its real reality. The deterioration of law in Indonesia is even more so. Public confidence in law enforcement has worsened. ${ }^{31}$

Legal injustice is a key word to explain the low level of public confidence in the legal institutions in Indonesia. According to Satjipto Rahardjo as a form of social crisis that afflicts our law enforcement officers, the things that arise in legal life are less well explained. This situation is less realized, in relation to legal life in Indonesia. ${ }^{32}$ Ongoing law enforcement practices, though formally legitimate (formal juridical) law, but moral legitimacy and social is very weak.

28 Amir Syamsuddin, dalam Diskusi RUU KUHAP Menuju Pembaruan Konsep Hakim Komisaris, Jakarta, pada tanggal 13 Februari 2009.

${ }^{29}$ Andi Hamzah, Guru Besar Ilmu Hukum Pidana Universitas Trisakti yang juga Ketua Tim Perumus RUU KUHAP dalam Simposium Nasional Masyarakat Hukum Pidana dan Kriminologi Indonesia, di Makassar 18-20 Maret 2013.

${ }^{30}$ Budiman Tanuredjo, RUU KUHAP Perkenalkan Hakim Pemeriksa Pendahuluan. http://nasional.kompas.com/read/2013/03/19/1130375/RUU.KUHAP.Perkenalkan.Hakim.Pemeriksa. Pendahuluan, diakses 4 Desember 2013.

${ }^{31}$ Ahmad Ali, Keterpurukan Hukum di Indonesia, Bogor: Ghalia Indonesia, 2005, hlm. 26.

${ }^{32}$ Satjipto Rahardjo, Membedakan Hukum Progresif, Jakarta: Kompas, 2008, hlm. 17. 
Constitutionally, the provision of Article 28D of the 1945 Constitution states that: "Everyone is entitled to the recognition, guarantee, protection, and fair legal certainty and equal treatment before the law". This constitutional basis is clear; every citizen has the right and equal treatment before the law. No discrimination in the law enforcement process. States, in this case law enforcement officials have an obligation in providing non-discriminatory legal justice, whether for big people or in power as well as small people who have no access to power politics and economics.

The same right before the law is also affirmed in the Law of Human Rights of the State Gazette Number 39 of 1999, State Gazette Number 165, and Supplement to the State Gazette Number 3886, in Article 3 states as follows:

"Everyone is entitled to the recognition, guarantee, protection, and fair treatment of law and to obtain legal certainty and equal treatment before the law. That is, legal justice is the right of every color of the country that must be guaranteed and protected by the state ".

Efforts to advance the role of law in addressing multidimensional for a long time and one of them with national criminal law reform, including in this case is the update of national criminal procedure law. Only up to the present KUHAP which was considered a masterpiece in the renewal of national criminal procedural law because it can replace the criminal law of colonial legacy is considered not in accordance with human rights in the realm of Indonesian independence, along with the development of ideas.

One of the fundamental principles in the KUHAP, namely the existence of a control institution called Pretrial. ${ }^{33}$ However, pre-trial in the KUHAP is considered to have a number weakness. First, the seizure and search process is not regulated as pre-trial. Second, the unequal position between the apparatus and the suspect is often intimidated and violent. Third, pretrial judges only prioritize the formal aspects rather than examine the material aspects because there is no obligation for investigators to prove the reasons for detention.

Narendra Jatna, ${ }^{34}$ said the idea of a Commissioner Judge is indispensable with the International Covenant on Civil and Political Rights ratified by Law Number 12 Year 2005 on Ratification of the International Covenant on Civil and Political Rights). In one of the provisions of the convention, it implies that any act of enforced efforts by law enforcement officers shall immediately be brought before the court.

The same thing is also conveyed by Former Kabareskrim Polri Komjen (Ret.) Ito Sumardi, ${ }^{35}$ involving the judge of the commissioner in the determination of the proper case whether or not to enter the court, will be contrary to the police work in conducting the cheap, quick and fair legal process, the countries used in the comparative study of France and the Netherlands are very different from the geographical conditions in Indonesia, and France itself is currently freezing the pattern of judges commissioners, while in the Netherlands such legal process has been removed.

33 RM. Pangabean, Sikap Polri terhadap Hakim Komisaris Dalam RUU KUHAP (Powerpoint), Disampaikan Dalam seminar. nasional Dalam Rangka Dies Natalis Universitas Trisakti, Jakarta, 2007.

${ }^{34}$ Narendra Jatna, Dosen Fakultas Hukum Universitas Indonesia, dalam Diskusi RUU KUHAP Menuju Pembaruan KUHAP di gedung LBH Jakarta, pada tanggal 13 Februari 2009.

35 Brigjen Pol. HS. Maltha, 13 Maret 2013, Detik News, RUU KUHAP: Mantan Kabareskrim Kritik Pembentukan Hakim Komisaris 
Romli Atmasmita, ${ }^{36}$ Professor of international criminal law from Padjadjaran University (Unpad), one of the experts who heard his opinion. The function and role of the commissioner judge in RKUHAP is not much different from pre-trial institution. That is filtering the authority of investigation and prosecution. The extension of authority to the commissioner's judge will not necessarily trigger the improvement of the criminal justice system. In fact the authority of investigators and prosecutors are more stringent. As a result, the criminal justice system does not run effectively and efficiently. The Criminal Code Draft is only a reference to procedural justice but it is difficult to achieve substantial justice. Therefore, deny the existence of judges commissioners in the draft of Criminal Procedure Code. He chose pre-trial institutions to be retained in the draft of Criminal Procedure Code. With note, the authority of pretrial institutions is expanded and reinforced by a strict supervisory system with pretrial mechanisms and processes.

Based on the draft of the Criminal Procedure Code, the chapter regulating the Preliminary Examining Judge states that the Preliminary Examining Judge is authorized to determine or decide: 1) The legitimacy of arrest, detention, search, seizure, or wiretapping; 2) Cancellation or suspension of detention; 3) A description made by a suspect or defendant by violating the right not to incriminate himself; 4) Unlawfully obtained evidence or statements can not be used as evidence; 5) Indemnify and / or rehabilitate for a person arrested or illegally detained or indemnified for any unlawfully confiscated property rights; 6) the suspect or defendant is entitled to or is required to be accompanied by a lawyer; 7) Investigations or prosecutions are conducted for unlawful purposes; 8) Termination of investigation or cessation of prosecution not based on the principle of opportunity; 9) Whether or not a case for prosecution is required; 10) Violations of any other suspects' rights that occurred during the investigation phase.

The provisions of the law are as follows: first, the Judge of Preliminary Examination gives a decision within 5 days at the latest calculated from the date of receipt of the request relating to the aforesaid authority. Second, the Examining Judge, the Preface provides a decision on the request based on the results of a research copy of a warrant for arrest, detention, seizure, or other relevant records. Third, the Preliminary Examination Judge may hear information from the suspect or his or her legal advisor, the investigator or the public prosecutor. Fourthly, if necessary, the Judge of Preliminary Examination is allowed to request relevant and sworn testimony of relevant witnesses and evidence. Fifth, the petition relating to the authority of the Preliminary Examination Judge above does not delay the investigation process.

When examining the Criminal Code Draft Law there are several criticisms as follows: First, in relation to the litigation model in the criminal justice system. It can not be denied that the draft Criminal Procedure Code is more inclined to the due process of law which focuses on the protection of the rights of suspects. This is equivalent to classical criminal law purposes that focus more on individual interests and not in order to protect people from crime.

Secondly, it is still related to the due process of law, there is a strong indication that the draft of Criminal Procedure Code refers to the model, namely the establishment of a judge investigating institution that philosophically rejects efficiency in the judicial process. This will intersect with the general principle of procedural law that recognizes the quick, simple, low cost principle.

${ }^{36}$ Romli Atmasmita, Guru Besar Rukum Pidana Internasional Universitas Padjajaran, 15 Maret 2013, AlitKritik Hakim Komisaris di RUU KUHAP, http://www.hukumonline.com/berita/baca 1t51431dd699b58/ahli-kritik-hakim-komisaris-di-rkuhap, diakses 9 Desember 2013. 
Third, due process produces procedures and substances of protection against individuals. ${ }^{37}$ Each procedure in the due process examines two things. 1), has the prosecutor removed the suspect's life, liberty and property without a procedure. 2), if using the procedure, whether the procedure pursued is appropriate with due process. ${ }^{38}$ It is not easy to apply due process of law in Indonesia, admitted by the legal circumstances that are full of judicial mafia practices.

Fourth, it is still related to the authority of the preliminary examiner judge in its implementation is not easy to implement given the geographical conditions in Indonesia. In a relatively short time should be able to confront the suspect physically to the preliminary hearing judge in the course of the extension of detention. The existence of a preliminary hearing judge shall be in any District Court in which jurisdictional territory is the same as the administrative area of a city or county government. In areas of eastern Indonesia consisting of many islands, one sub-district consists of one even several islands. With limited means of transportation, it is not easy to physically face the suspect to a state court, not to mention the safety factor.

Fifth, in the future Criminal Procedure Code, there should be a proportional protection of interests. This is in accordance with the doctrine of the existence of a criminal law that must protect the three interests, each of which is individuale belangen (interests of the individual), sociale of maatschappelijke belangen (interests of social interest or society) and staatsbelangen (interests of state interest). The criminal law serves to counter abnormal actions as described by Vos "... het starfrecht zich richt tegen min of meer abnormale gedragingen". ${ }^{39}$ The actions of abnormal actions in question are actions that affect the interests of the individual, the interests of society and the interests of the state. Therefore, an idolized criminal procedural law must have a balance of protection between individual interests in this case perpetrators of crimes, disturbed public interest due to crime victims and state interests in prosecution and punishment.

Sixth, as a solution to balance the protection of proportional interests between the actions of law enforcement officials and the protection of human rights is to optimize pre-trial institutions. That is, pretrial can be made against all the forced attempts that law enforcement officers can take against suspects and / or defendants. There should also be clarity on the status of the suspect, if the case has never been processed, while a person has been declared a suspect.

\section{Conclusion}

The existence of a judge commissioner which had a view in order to have a guarantee the protection of human rights of a person, who is a suspect / defendant in the criminal justice process. With the existence of the judges, the commissioners prevented different views on the validity of legal action on the preliminary examination, namely the validity of arrest, detention, search and seizure because the legal action relates to the issue of human rights as the defendant, namely freedom and freedom, wealth and protection against security and peace.

${ }^{37}$ Rhonda Wasserman, Procedural Due Process: A Refernce Guide to the United States Constitution, Greenwood Publishing Grup, 2004, hlm. 1

${ }^{38}$ Ibid, hlm. 31

${ }^{39}$ H.B. Vos, Leerboek Van Nederlands Strafrecht, Derde Herziene Druk, HD Tjeenk Willink \& Zoon N.V. - Haarlem, 1950, hlm. 136 
Guarantee on the protection of the rights of suspects / defendants in the preliminary examination stage as a manifestation of the function of criminal procedural law is to conduct a fair trial in order to discover the material truth or the essential truth. And the forced attempts by the Investigator to obtain sufficient initial evidence are not only submitted unilaterally to the investigator but there must be a test conducted by the commissioner's judge.

\section{References}

\section{Books:}

[1]. Ahmad Ali, Keterpurukan Hukum di Indonesia, Bogor: Ghalia Indonesia, 2005

[2]. Ahmad Ubbe, Proses Pengadilan dalam Perkara Pidana, Jakarta: BPHN- KemkumHam, 2009

[3]. Apeldoorn, L.J. van, Pengantar Ilmu Hukum, Pradnya Paramita, Jakarta, 1975

[4]. Bhardwaj, H.R., Crime, Criminal Justice \& Human Rights, New Delhi, Konark Publisher Pvt. Ltd., 2001

[5]. H.B. Vos, Leerboek Van Nederlands Strafrecht, Derde Herziene Druk, HD Tjeenk Willink \& Zoon N.V. - Haarlem, 1950

[6]. Indriyanto Seno Adji, KUHAP dalam Perspektif, Jakarta: Diadit Media, 2011

[7]. Kaligis, O.C. Praktik Pra peradilan Dari Waktu Ke Waktu, Otto Cornelis Kaligis \& Associates, Jakarta, tahun 2000

[8]. Loebby Loqman. Pra peradilan di Indonesia. Jakarta: Ghalia Indonesia, 1984

[9]. Rhonda Wasserman, Procedural Due Process: A Refernce Guide to the United States Constitution, Greenwood Publishing Grup, 2004

[10].Roni Hanitijo Soemitro, Metode Penelitian Hukum dan Jurimetri, Jakarta: Ghalia Indonesia, 1983

[11].Satjipto Rahardjo, Membedakan Hukum Progresif, Jakarta: Kompas, 2008

[12]. Soerjono Soekanto \& Sri Mamudji, Penelitian Hukum Normatif, Jakarta: Rajawali, 1985

[13].Supanto, Kejahatan Ekonomi Global dan Kebijakan Hukum Pidana, Bandung: Alumni, 2010

[14].Yanto, Hakim Komisaris dalam Upaya Perlindungan Terhadap Hak Asasi Manusia, Disertasi, Jakarta: FH Jayabaya, 2010

\section{Papers:}

[1]. Amir Syamsuddin, dalam Diskusi RUU KUHAP Menuju Pembaruan Konsep Hakim Komisaris, Jakarta, pada tanggal 13 Februari 2009.

[2]. Andi Hamzah, Guru Besar Ilmu Hukum Pidana Universitas Trisakti yang juga Ketua Tim Perumus RUU KUHAP dalam Simposium Nasional Masyarakat Hukum Pidana dan Kriminologi Indonesia, di Makassar 18-20 Maret 2013.

[3]. Gregory Churchill. Habeas Corpus: Peranan Upaya Habeas Corpus Dalam Pengawasan Pelaksanaan Hukum Acara Pidana di Amerika Serikat. Seminar Pra peradilan, PERADIN. Jakarta, 1982

[4]. Narendra Jatna, Dosen Fakultas Hukum Universitas Indonesia, dalam Diskusi RUU KUHAP Menuju Pembaruan KUHAP di gedung LBH Jakarta, pada tanggal 13 Februari 2009.

[5]. RM. Pangabean, Sikap Polri terhadap Hakim Komisaris Dalam RUU KUHAP (Powerpoint), Disampaikan Dalam seminar. nasional Dalam Rangka Dies Natalis Universitas Trisakti, Jakarta, 2007.

\section{Website:}

[1]. Budiman Tanuredjo, RUU KUHAP Perkenalkan Hakim Pemeriksa Pendahuluan. http://nasional.kompas.com/read/2013/03/19/1130375/RUU.KUHAP.Perkenalkan.Hakim.Pemeriks a.Pendahuluan, diakses 4 Desember 2013.

[2]. http://dekade80.blogspot.com/2009/04/sengkon-dan-karta-sebuah-ironi-keadilan.html di unduh pada tanggal 29 April 2012 
[3]. Romli Atmasmita, Guru Besar Rukum Pidana Internasional Universitas Padjajaran, 15 Maret 2013, AlitKritik Hakim Komisaris di RUU KUHAP, http://www.hukumonline.com/berita/baca 1t51431dd699b58/ahli-kritik-hakim-komisaris-di-rkuhap, diakses 9 Desember 2013. 